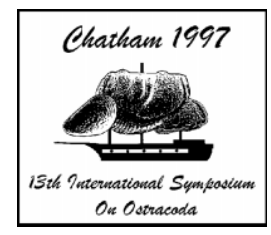

Marine Micropaleontology 37 (1999) 231-249

www.elsevier.com/locate/marmicro

\title{
Deep-sea ostracode species diversity: response to late Quaternary climate change
}

\author{
Thomas M. Cronin ${ }^{\mathrm{a}, *}$, Dawn M. DeMartino ${ }^{\mathrm{a}}$, Gary S. Dwyer ${ }^{\mathrm{b}}$, Julio Rodriguez-Lazaro ${ }^{\mathrm{c}}$ \\ a 955 U.S. Geological Survey, Reston, VA 20192, USA \\ ${ }^{b}$ Division of Earth and Ocean Sciences, Duke University, Durham, NC 27708, USA \\ ${ }^{c}$ Department of Paleontology, University Pais Vasco, Bilbao, Spain
}

Received 1 October 1997; accepted 16 November 1998

\begin{abstract}
Late Quaternary ostracode assemblages from the North Atlantic Ocean were studied to establish the effect of climatic changes of the past 210,000 yr (marine oxygen isotope stages 7-1) on deep-sea benthic biodiversity and faunal composition. Two-hundred and twenty five samples from the Chain $82-24$ Core $4 \mathrm{PC}\left(41^{\circ} 43^{\prime} \mathrm{N}, 32^{\circ} 51^{\prime} \mathrm{W}, 3427 \mathrm{~m}\right.$ water depth) on the western Mid-Atlantic Ridge revealed high amplitude fluctuations in ostracode abundance and diversity coincident with orbital and suborbital scale climate oscillations measured by several paleoceanographic proxy records. During the past $210,000 \mathrm{yr}$, ostracode biodiversity as measured by species number $(S)$ and the Shannon-Weaver index, $H(S)$, oscillated from $H(S)=0.4$ during glacial periods (marine isotope stages $6,5 \mathrm{~d}, 5 \mathrm{~b}, 4$, and 2) to $H(S)=1.1$ during interglacial and interstadial periods (stages 7, 5e, 5c, 5a, 3 and 1). A total of 23 diversity peaks could be recognized. Eleven of these signify major periods of high diversity $[H(S)>0.8, S=10-21]$ occurring every 15-20 ka. Twelve were minor peaks which may represent millennial-scale diversity oscillations. The composition of ostracode assemblages varies with Krithe-dominated assemblages characterizing glacial intervals, and Argilloecia-Cytheropteron characterizing deglacials, and trachyleberid genera (Poseidonamicus, Echinocythereis, Henryhowella, Oxycythereis) abundant during interglacials. Diversity and faunal composition changes can be matched to independent deep-sea paleoceanographic tracers such as benthic foraminiferal carbon isotopes, Krithe trace elements $(\mathrm{Mg} / \mathrm{Ca}$ ratios), and to North Atlantic region climate records such as Greenland ice cores. When interpreted in light of ostracode species' ecology, these faunal and diversity patterns provide evidence that deep-sea benthic ecosystems experience significant reorganization in response to climate changes over orbital to millennial timescales. Published by Elsevier Science B.V.
\end{abstract}

Keywords: paleoceanography; ostracodes; species diversity; deep-sea

\section{Introduction}

The response of the world's ecosystems to climate change has emerged as a major environmental issue as concern increases about the potential im-

\footnotetext{
* Corresponding author.
}

pact of future human-induced climate changes on the world's biotas (e.g., Peters and Lovejoy, 1992). Although the deep-sea had been considered a fairly stable environment, fostering relatively high benthic species diversity (Hessler and Sanders, 1967; see Rex et al., 1993), paleoceanographers have shown that deep-sea circulation responds dynamically to 
global climate changes (e.g. Boyle and Keigwin, 1982, 1987; Broecker et al., 1985; Raymo et al., 1989, 1992) and that deep-sea benthic faunas respond to glacial-interglacial climate changes in general (Schnitker, 1979) and specifically in response to climate-induced variability in food resources (Gooday, 1988; Thomas et al., 1995). Recently, Cronin and Raymo (1997) showed that orbital-scale climate change such as 41,000-yr obliquity cycles have a major impact on deep-sea benthic communities in the North Atlantic Ocean.

In addition to orbital scale climate change and diversity variability at orbital timescales, recent studies of high-sedimentation regions of the North Atlantic Ocean (Keigwin and Jones, 1994; Keigwin, 1995) demonstrate that past deep-ocean circulation changes occurred over centennial to millennial timescales as well. Do these shorter-term Quaternary climate changes cause deep-sea diversity changes? And, if so, what factors influence diversity most? These questions are especially pertinent because coupled atmosphere-ocean climate models predict major changes in North Atlantic thermohaline circulation over the course of the next few centuries (Manabe and Stauffer, 1995).
In this study we examined the response of deepsea ostracode biodiversity to changes in benthic environments related to climate changes over the past 210,000 years in the North Atlantic Ocean. Our goal was to specifically address the question as to whether shorter-term climate changes ( 2 to $20 \mathrm{kyr}$ ) lead to diversity changes. Moreover, recent field studies of terrestrial diversity have shown that diversity itself is not the major attribute to maintain a functioning ecosystem, but rather it is the species composition as well (e.g. Tilman et al., 1997; Hooper and Vitousek, 1997). Therefore, in addition to obtaining secular trends in diversity, we also examined how benthic assemblage composition changes at these timescales by examining trends in key ostracode taxa indicative of climatically driven ecosystem dynamics.

\section{Core site and material}

The Chain Core 82-24 4PC site (Fig. 1) is situated on the western flank of the Mid-Atlantic Ridge in a region dominated during the current interglacial by North Atlantic Deep Water (NADW) (Boyle and Keigwin, 1985; Raymo et al., 1989, 1992). We chose

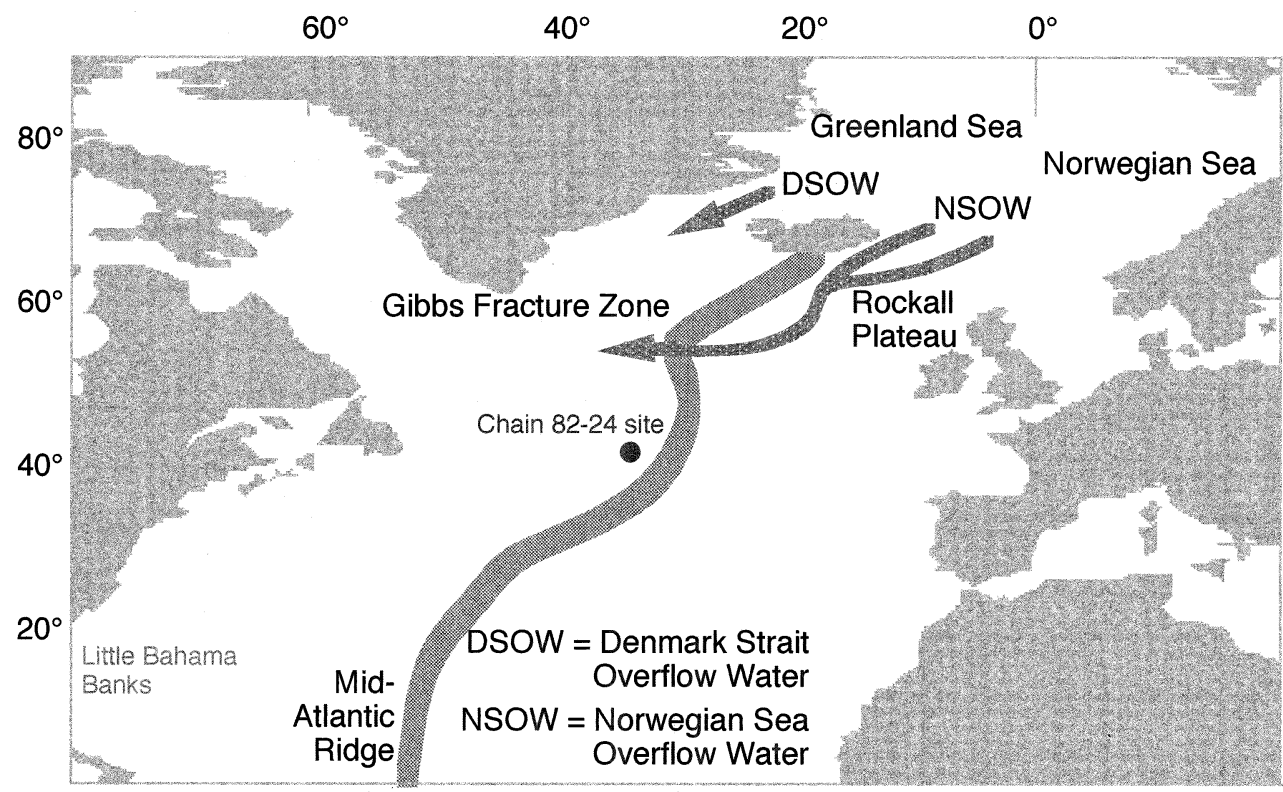

Fig. 1. Map showing location of Chain 82-24 core 4PC site in relation to sources of North Atlantic deep water originating in Nordic Seas. 
this site to investigate ostracode diversity during climate change for several reasons. First, this region has a well-established late Neogene paleoceanographic history based on multiple proxy faunal and stable isotopic records from the Chain 82-24 core (Boyle and Keigwin, 1985) and Deep Sea Drilling Program (DSDP) Site 607 (Ruddiman et al., 1986; Raymo et al., 1989). These records include planktic and benthic foraminiferal abundances and shell $\delta^{18} \mathrm{O}$, $\delta^{13} \mathrm{C}$, and cadmium/calcium $(\mathrm{Cd} / \mathrm{Ca})$ ratios (Boyle and Keigwin, 1985), and ostracode shell magnesium : calcium $(\mathrm{Mg} / \mathrm{Ca})$ ratios (Dwyer et al., 1995; Cronin et al., 1999). In brief, these studies show that over at least the last 3 million years, the site is influenced by NADW during interglacials and more so by Antarctic Bottom Water (AABW) during glacials (Raymo et al., 1992). The ostracodes studied here were obtained from the same samples used by Boyle and Keigwin (1985) in their original study of isotopic and trace element variability in the Chain 82-24 core and those used by Dwyer et al. (1995) and Cronin et al. (1999) to study $\mathrm{Mg} / \mathrm{Ca}$ ratios in Krithe shells.

Another advantage of the Chain core is that it is located at the site of Deep Sea Drilling Project Site 607 where extensive Plio-Pleistocene ostracodebased biostratigraphic (Whatley and Coles, 1987), biodiversity (Cronin and Raymo, 1997), and paleoceanographic reconstructions (Dwyer et al., 1995; Cronin, 1996; Cronin et al., 1996) have been carried out. Thus, these data provide a comparative data base on pre-late Quaternary, low-frequency benthic faunal trends to which we can compare those that occurred during the last 210,000 years.

Adequate taxonomy is a prerequisite for investigating the impact of climate change on diversity. The taxonomy of deep-sea North Atlantic ostracodes is reasonably well known (Whatley and Coles, 1987) and species-level taxonomic identification was possible for most groups. One difference between the present study and the previous study of DSDP Site 607 ostracode diversity by Cronin and Raymo (1997), is that in the present study, we followed the taxonomy of Coles et al. (1994) for identifying species of the dominant deep-sea genus Krithe.

The Chain core also has an excellent age model (Boyle and Keigwin, 1985) based primarily on oxygen isotope stratigraphy. Boyle and Keigwin noted a gap in coring between about 350 and $380 \mathrm{~cm}$, which they corrected by subtracting $30 \mathrm{~cm}$ from the core depth below $380 \mathrm{~cm}$ to obtain a continuous paleoceanographic sequence. We provide the original sample core depths in Table 1; Fig. 2 plots abundance and diversity against corrected core depth.

We analyzed 266 total samples of which 258 samples were included in the plots of species diversity and ostracode assemblages. The ostracode species census data are given in Table 1. We picked all adult and juvenile (molt) ostracodes contained in the $>150$ $\mu \mathrm{m}$ size fraction. This method assured that all adults and, depending on the species, usually two to three prior molt stages were obtained.

\section{Ostracode abundance and diversity}

Fig. 2 plots ostracode total abundance in each sample $(N,>150 \mu \mathrm{m})$ and diversity as measured by both number of species $(S)$ and by the Shannon-Weaver information function, $H(S)$ $\left[H(S)=\sum_{1}^{n} p_{i} \ln \left(p_{i}\right)\right.$ where $p_{i}$ is the proportion of the $i$ th species, $\ln$ is the natural $\log , n$ is the total number of species]. $H(S)$ is one of many available indices to measure diversity; it has the advantage that it takes into account both the number of species and their relative proportions. A maximum value of $H(S)$ would occur when all species are equally distributed in a sample.

As shown in Fig. 2, the number of individuals in any sample varies greatly from 0 to almost 150 ; the mean was about 40 for all samples (Table 1). $S$ varies from 1-2 species to as many as 20 species in a single sample; $H(S)$ varies from about 0.4 to almost 1.2 .

It is well known that the fewer individuals in a sample, the greater the chance that rare species are missed. In such cases, an ecosystem's true diversity would be underestimated. Consequently, it would be preferable to have 200-300 individual specimens per sample to analyze trends in diversity. There are not, however, enough ostracode specimens in each sampled 2 to $4 \mathrm{~cm}$ interval to do this. One way to overcome the problem of small sample size would be to group assemblages from several samples from a $10-20-\mathrm{cm}$ interval and thereby obtain a greater sample size. This solution has several drawbacks. First, it sacrifices the temporal resolution from using $2-4 \mathrm{~cm}$ 


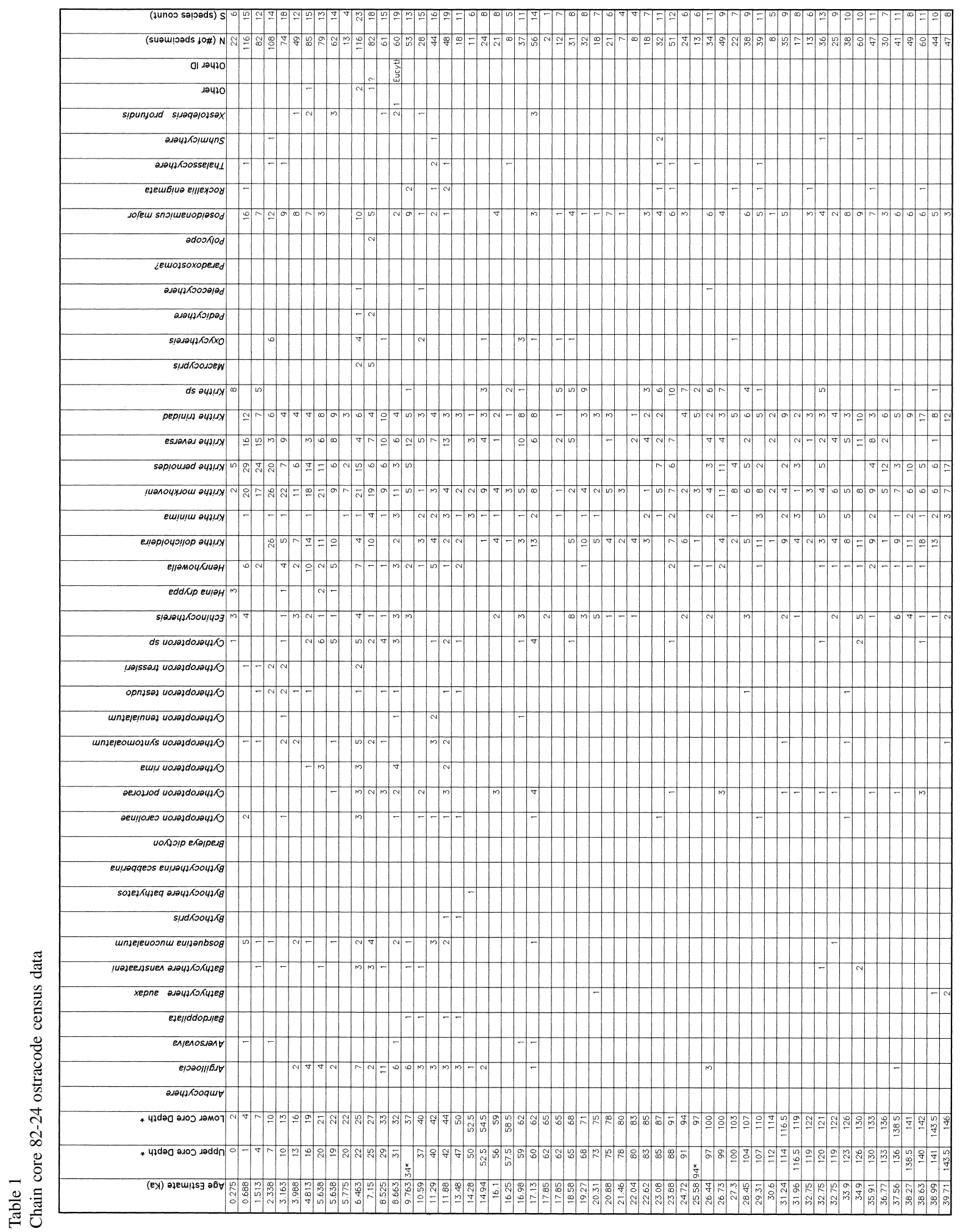




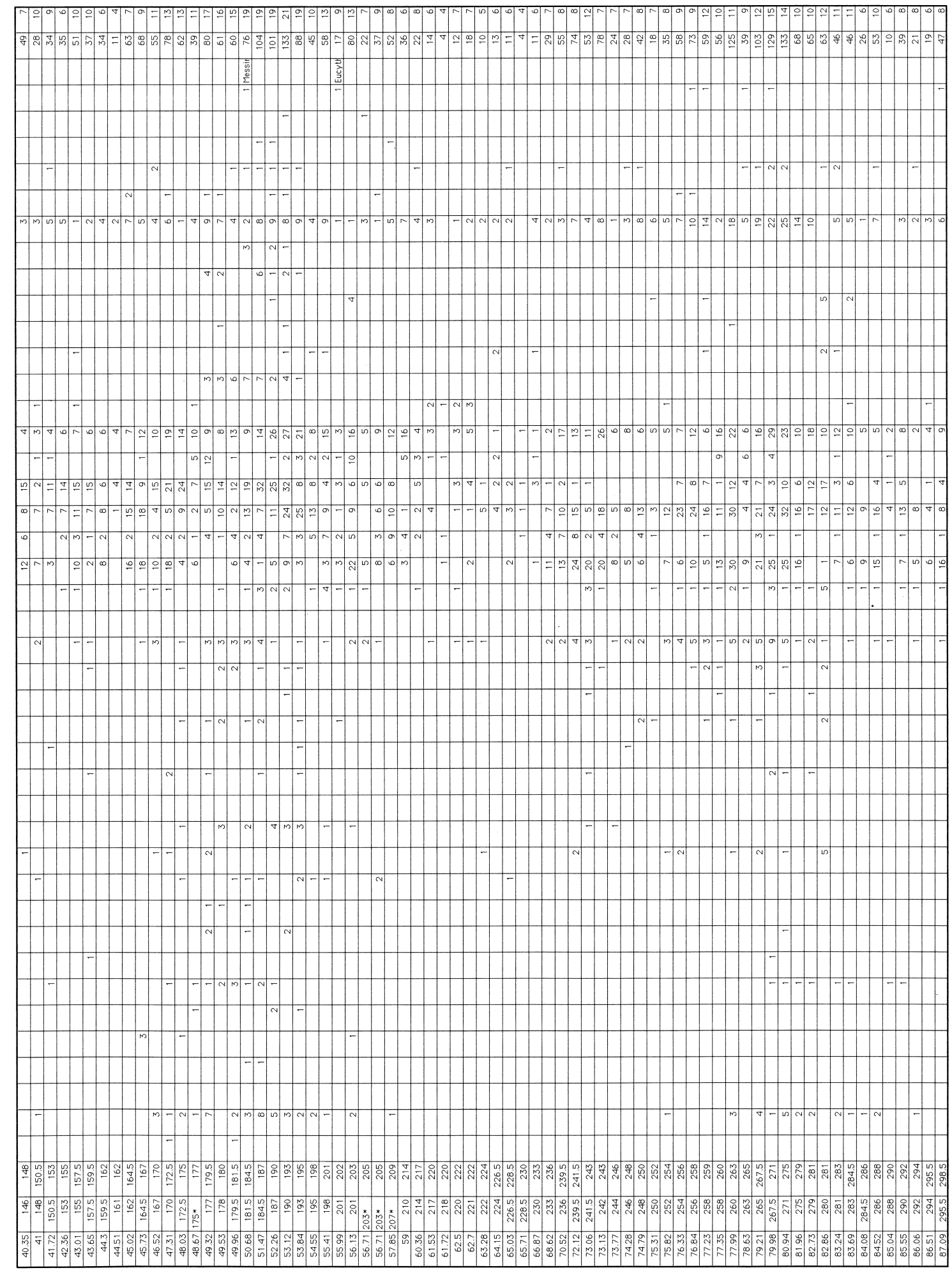




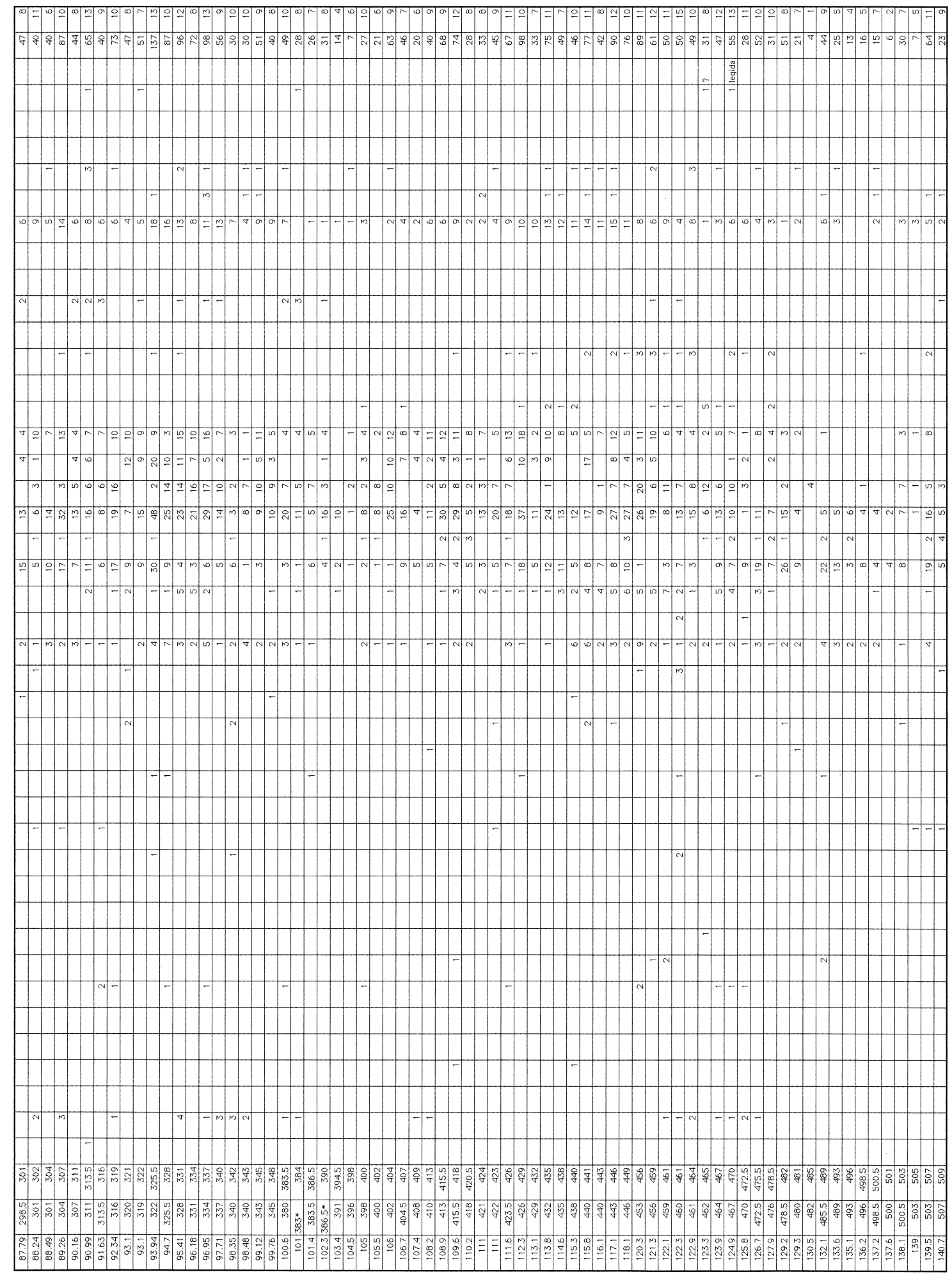




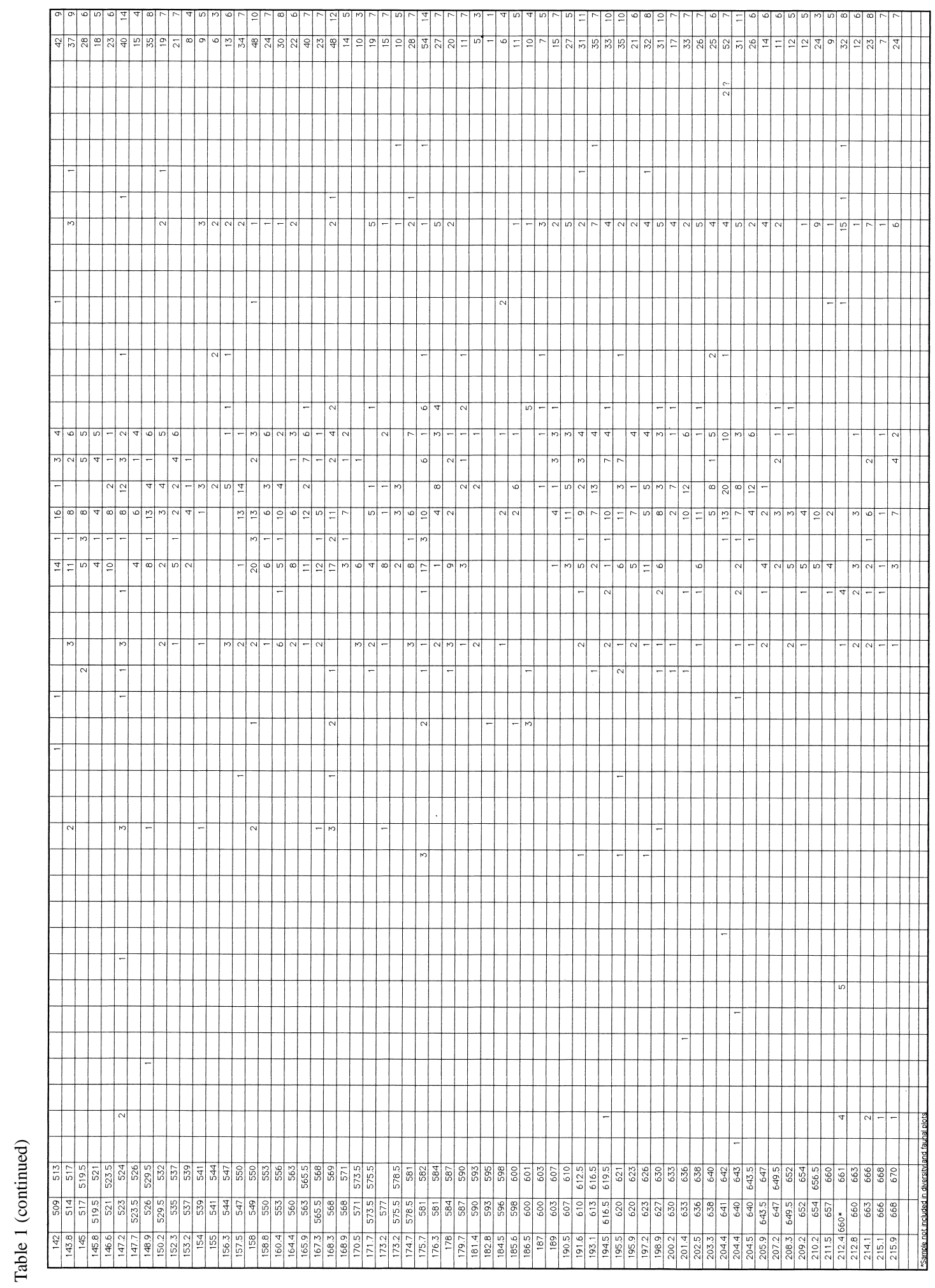



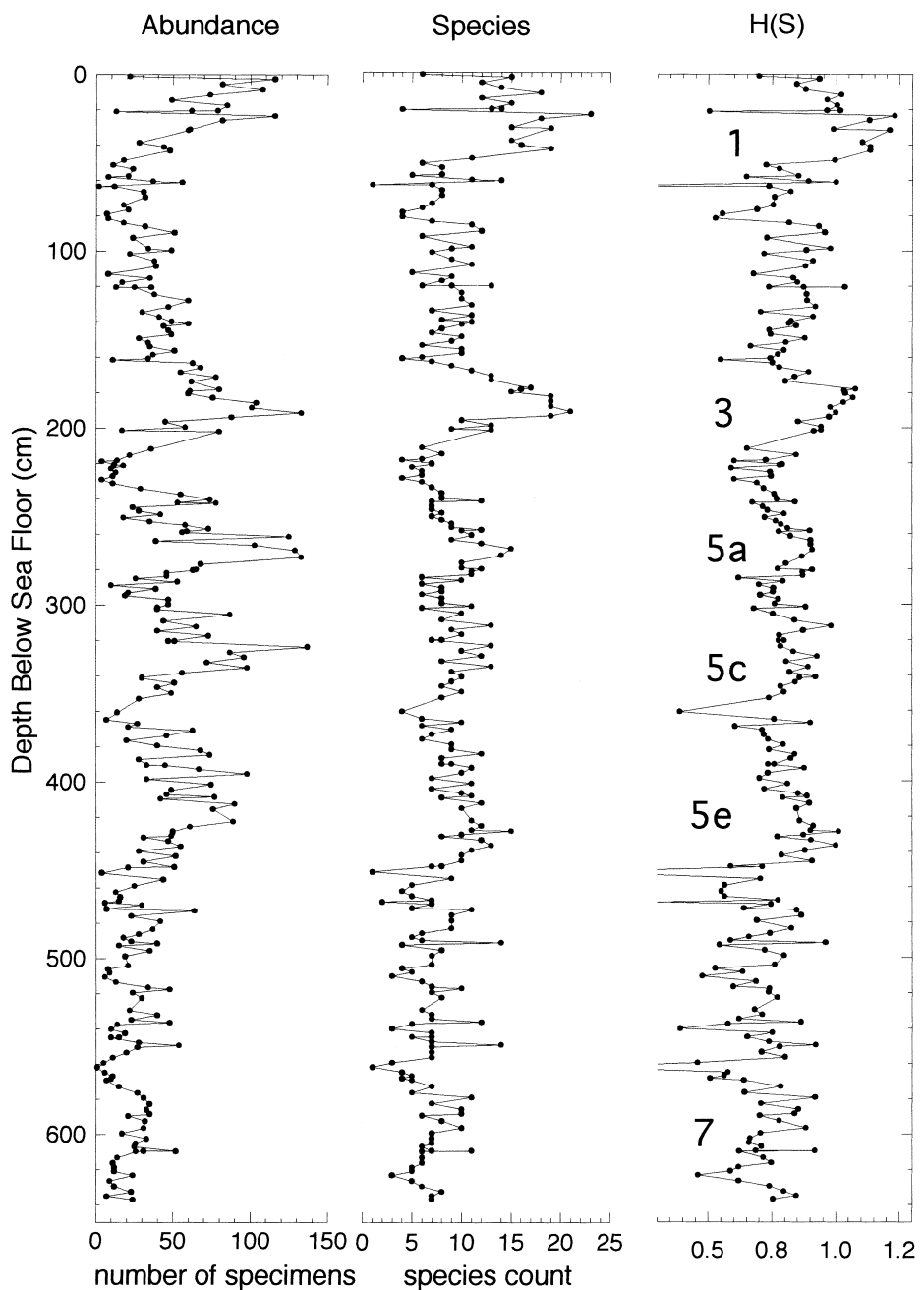

Fig. 2. Plot of ostracode abundance, species number and species diversity measured by $H(S)$ (Shannon Weaver Index) for the Chain 82-24 core 4PC, western mid-Atlantic Ridge, North Atlantic Ocean. Original core depths below $347 \mathrm{~cm}$ have been corrected by subtracting $32 \mathrm{~cm}$ from core depth per Boyle and Keigwin (1985) to account for a gap in the coring. Odd-numbered oxygen isotope stages $(1,3,5 a, 5 c, 5 e$, and 7$)$ are labeled for reference to later figures.

sampling intervals and might obscure rapid changes in ostracode faunas. Second, it makes direct comparison between ostracode trends and paleoceanographic isotopic and trace element indicators obtained from the same sample splits more difficult. Third, the changes in ostracode abundance may in fact reflect environmentally influenced biotic factors, such as changes in standing stock of ostracodes, as well as sedimentological and post-mortem taphonomic processes. A fourth reason is that the $H(S)$ index is not as sensitive to total abundance as is simple species number, $S$, and using $H(S)$ to measure diversity overcomes the low abundances to a certain degree. This is illustrated in Fig. 3 which plots $N$ versus both $S$ and $H(S)$ for our data set and illustrates the common relationship between abundance and diversity. Diversity as measured by $H(S)$ increases with abundance asymptotically such that obtaining greater numbers of specimens may lead to the discovery of only rare species. The curve of $N$ versus $H(S)$ tends to level out with increasing abundance and thus is less likely to be biased by low num- 

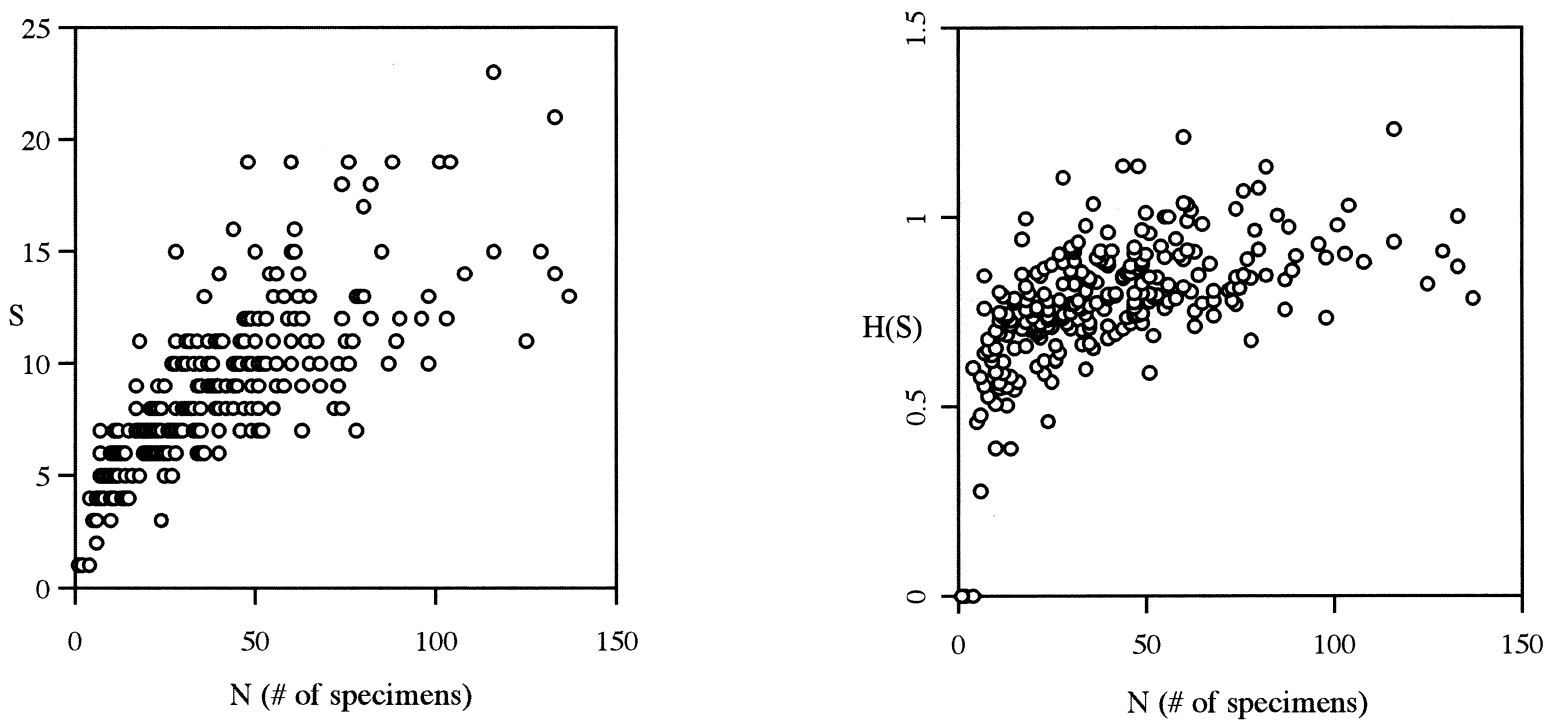

Fig. 3. Plot showing relationship between number of ostracode species $(S)$ and diversity $[H(S)]$ and number of specimens. Using $H(S)$ as an index of diversity lessens the effects of low abundance on estimating real species diversity.

bers of individuals. For example, the most diverse samples $[H(S)>1]$ are not those with the greatest abundance, but those that have $<50$ to about 100 individuals, whereas samples with the greatest abundance ( $>100$ specimens) have moderate diversity $[H(S)=0.75-1.0]$. Samples with $<20$ individuals clearly must be suspected of missing certain taxa. We compared diversity trends using all 256 samples with trends obtained using only a subset consisting only of samples with $>20$ specimens with little apparent differences in the major trends.

In sum, the strategy to investigate diversity trends represents a tradeoff between maintaining the temporal resolution and paleoenvironmental context necessary to test ideas about climate and benthic communities and the desired adequate representation of rare taxa. We consider the diversity trends to represent a first order benthic signal, though certainly less common species are underrepresented in some samples, and the abundance trends themselves may also signify ecological changes over millennial timescales. We hope our preliminary results lead to additional research using cores in which more sediment can be sacrificed to obtain larger numbers of individual ostracode specimens and provide a stronger statistical basis for inferring diversity trends.

\section{Diversity, climate and deep-sea environmental change}

\subsection{Diversity and paleoceanographic changes in the deep North Atlantic}

We first compared $H(S)$, using a three-point moving average to $\mathrm{Mg} / \mathrm{Ca}$ ostracode shell ratios and the benthic foraminiferal carbon and oxygen isotopic curves from Boyle and Keigwin (1985) for the last $210 \mathrm{ka}$ to examine the diversity/climate linkage at this site (Fig. 4; Table 2). We identified 23 total excursions in diversity, labeled 1-23 in Fig. 4 (see Table 2). Eleven of these diversity peaks (DPs) are periods when $H(S)$ exceeded 0.8 and $S$ ranged from 10 to 21 species (DPs 1, 4/5, 6/7, 8/9, 11, 12/13, $15,17,20,21,23)$. Most of these peaks correspond to periods of global climatic warmth defined by oddnumbered marine isotope stages (MIS) as follows: MIS $1=$ DP 1 ; MIS $3=$ DP 8 ; MIS 5a = DP 11; MIS $5 \mathrm{c}=$ DP 13 ; MIS 5e $=$ DP 15 ; MIS $7=$ DP $21 / 23$. Other notable features of the smoothed $H(S)$ curve are that the highest $H(S)$ values correspond to the early Holocene hypsithermal and isotope stage 3, and that there are multiple periods of high diversity during isotope stage 6 (DPs 17-20). 

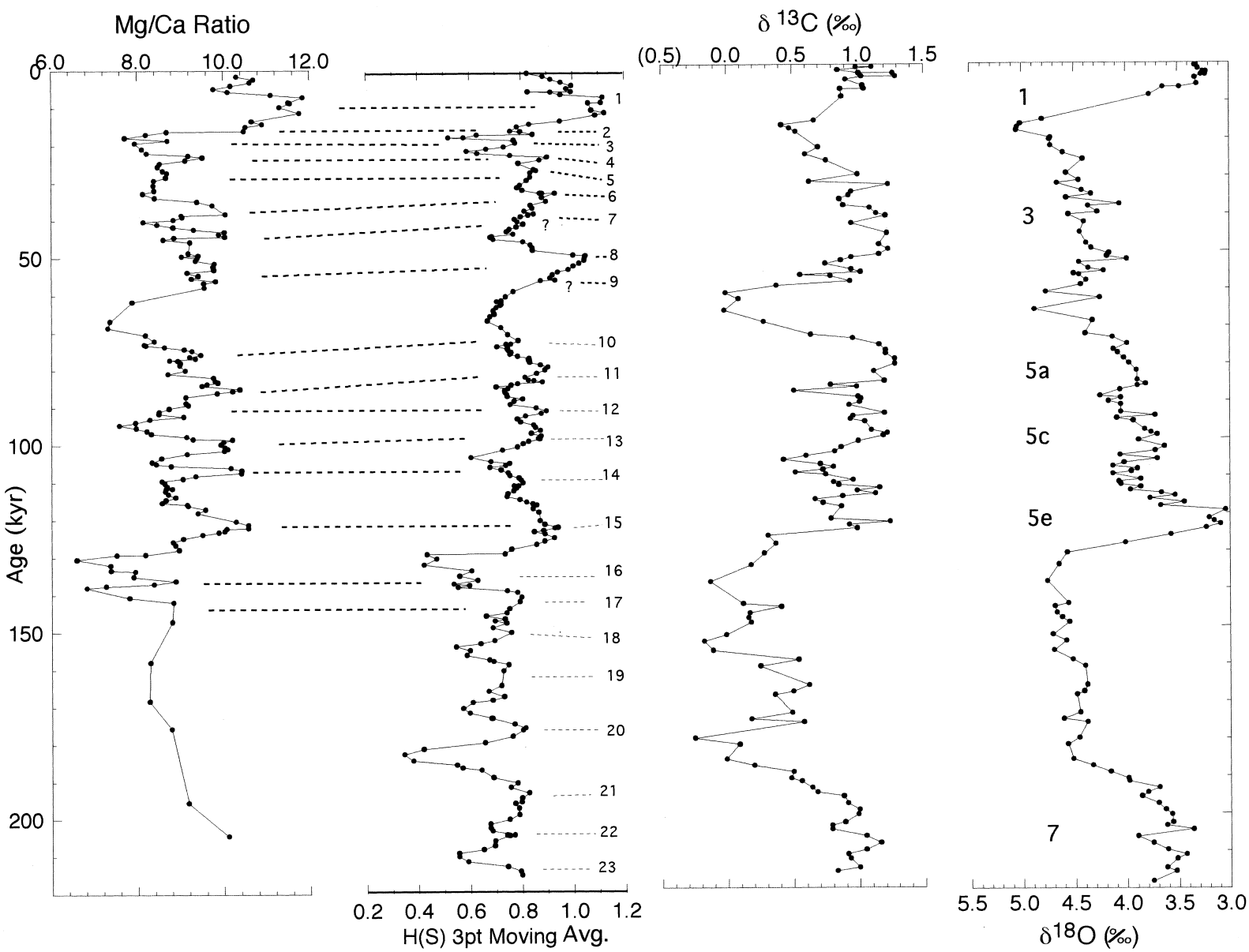

Fig. 4. Comparison of ostracode diversity [three-point moving average of $H(S)$ ] and $\mathrm{Mg} / \mathrm{Ca}$ ratio of Krithe shells, $\delta^{13} \mathrm{C}$ and $\delta^{18} \mathrm{O}$ of $C$. wuellerstorfi. Twenty-three diversity peaks (DPs) are labeled in the second column; tentative correlation to spikes in $\mathrm{Mg} / \mathrm{Ca}$ values signifying relatively warm bottom water temperatures are shown with dotted lines. Odd-numbered marine oxygen isotope stages signifying interglacial climates are labeled at right. Age model is that of Boyle and Keigwin (1985). Not all samples yielded both adult Krithe for $\mathrm{Mg} / \mathrm{Ca}$ measurements and adequate specimens for diversity measure. These sampling biases, plus the effects of smoothing, bioturbation and a possible lagged response of diversity, mean that the ages of peaks in $\mathrm{Mg} / \mathrm{Ca}$ and $H(S)$ do not always match exactly. Resolution of these fine-scale differences between $H(S)$ and $\mathrm{Mg} / \mathrm{Ca}$ requires studies of higher sedimentation rate situations.

Periods of high diversity also correspond to relatively warm bottom water temperatures (BWT) indicated by high $\mathrm{Mg} / \mathrm{Ca}$ ratios. $\mathrm{Mg} / \mathrm{Ca}$ ratios ranging from 10 to $12 \mathrm{mmol} / \mathrm{mol}$ suggest BWT from 3 to $3.5^{\circ} \mathrm{C}$ using the $\mathrm{Mg} / \mathrm{Ca}$ temperature calibration of Dwyer et al. (1995). Modern BWT at the Chain core sites is about $2.3^{\circ} \mathrm{C}$. In contrast, periods of lowest diversity had estimated BWT equal to $0-1^{\circ} \mathrm{C}$. In general, the record of first-order diversity variability suggests that it is related to deep-sea environmental changes occurring at orbital timescales of $20-100$ ka which dominate many climate records of the past $200 \mathrm{kyr}$.

Millennial-scale changes in diversity are also evident from the data in Figs. 2 and 4. Although the sedimentation rate was too slow to determine the exact frequency and duration of each event, minor diversity excursions appear to correspond to excursions in $\mathrm{Mg} / \mathrm{Ca}$ ratios (Fig. 4). For example, during the past $150 \mathrm{kyr}$, an interval for which $\mathrm{Mg} / \mathrm{Ca}$ data are available at a sampling resolution comparable to that for diversity, 15 of 17 DPs have a correspond- 
Table 2

Ostracode diversity peaks, Dansgaard-Oeschger events, $\mathrm{Mg} / \mathrm{Ca}$ peaks

\begin{tabular}{llll}
\hline Diversity peak & Dansgaard-Oeschger Event & Mg/Ca peak & Comments \\
\hline 1 & hypsithermal & yes & double peak \\
2 & $1 ?$ & yes & \\
3 & $1 ?$ & yes & \\
4 & 2 & yes & \\
5 & 3 & $?$ & DP and Mg/Ca peaks not coincident \\
6 & 8 & yes & weak DP peak \\
7 & 12 & yes & strong DP peak \\
8 & 14 & yes & weak DP peak \\
9 & 15 & yes & \\
10 & $19 / 20$ & yes & double peak \\
11 & 21 & yes & \\
12 & 22 & $?$ & \\
13 & 23 & yes & double peak \\
14 & 24 & yes & \\
15 & & yes & \\
16 & & yes & \\
17 & & yes & \\
$18-23$ & no data & no data & \\
\hline
\end{tabular}

ing excursion in $\mathrm{Mg} / \mathrm{Ca}$; the two exceptions are DP 12 and DP 5 (Table 2). We caution that the effects of small sample size, curve-smoothing in Figs. 4 and 5, and sedimentation can obscure fine details of the actual diversity history of this region. This is especially pertinent as the net diversity change during rapid excursions is only 0.2 to 0.5 [e.g., $H(S)$ changes from 0.5 to 0.8 ]. Even with this limitation, the apparent correspondence of even minor changes in BWT with ostracode diversity suggests the trends are not a sampling or preservation artifact but rather that $H(S)$ successfully captures real high-frequency diversity variability that is somehow linked to the same environmental changes that caused the temperature variability. To cite one example, the drop in diversity between DP 2 and DP 1 occurs during the well-known 1000-year climate reversal Younger Dryas (Broecker et al., 1985; Lehman and Keigwin, 1992). Two major diversity peaks, DP 1 and DP 11, have double peaks that correspond to double peaks in $\mathrm{Mg} / \mathrm{Ca}$ ratios.

\subsection{Comparison with other climatic records}

Because deep-sea diversity appears to be linked to deep- and surface-water paleoceanographic variability in the North Atlantic region, it is instructive to compare diversity to other records of climate change in the North Atlantic region. The GISP 2 and GRIP Greenland ice cores provide a detailed climate records of the past $110 \mathrm{kyr}$ (Dansgaard et al., 1993; Johnsen et al., 1992; Stuiver et al., 1995; Brook et al., 1996; Alley et al., 1997). Fig. 5 compares the smoothed diversity record against the GISP2 oxygen isotope curve for $\delta^{18} \mathrm{O}$ of Greenland ice, considered mainly a record of atmospheric temperatures of the source of precipitation over Greenland, secondarily influenced by atmospheric circulation (Stuiver et al., 1995). Although the ice core sampling exceeds that of the Chain core and the age models are somewhat different, several first-order similarities and differences are apparent. During the latter part of marine isotope stage $5(110-80 \mathrm{ka})$, four DPs $[H(S)>0.8]$ are tentatively correlated with light isotope excursions in the Greenland record centered at approximately $110,95-98,90$ and about 80 kyr. These are the equivalent of Dansgaard-Oeschger (D-O) interstadial events \#24, 23, 22, and 21, respectively, recognized in the GRIP ice core (Johnsen et al., 1992; Dansgaard et al., 1993). There are no diversity excursions during the brief but strong $\mathrm{D}-\mathrm{O}$ events \#19 and 20 about 68 and $72 \mathrm{kyr}$. The major DP centered on $50 \mathrm{kyr}$ (= DP \#8, Fig. 4) corresponds to Dansgaard-Oeschger event \#14; the interval of 
Diversity $[H(S)]$ vs. GISP2 Ice

Core Record
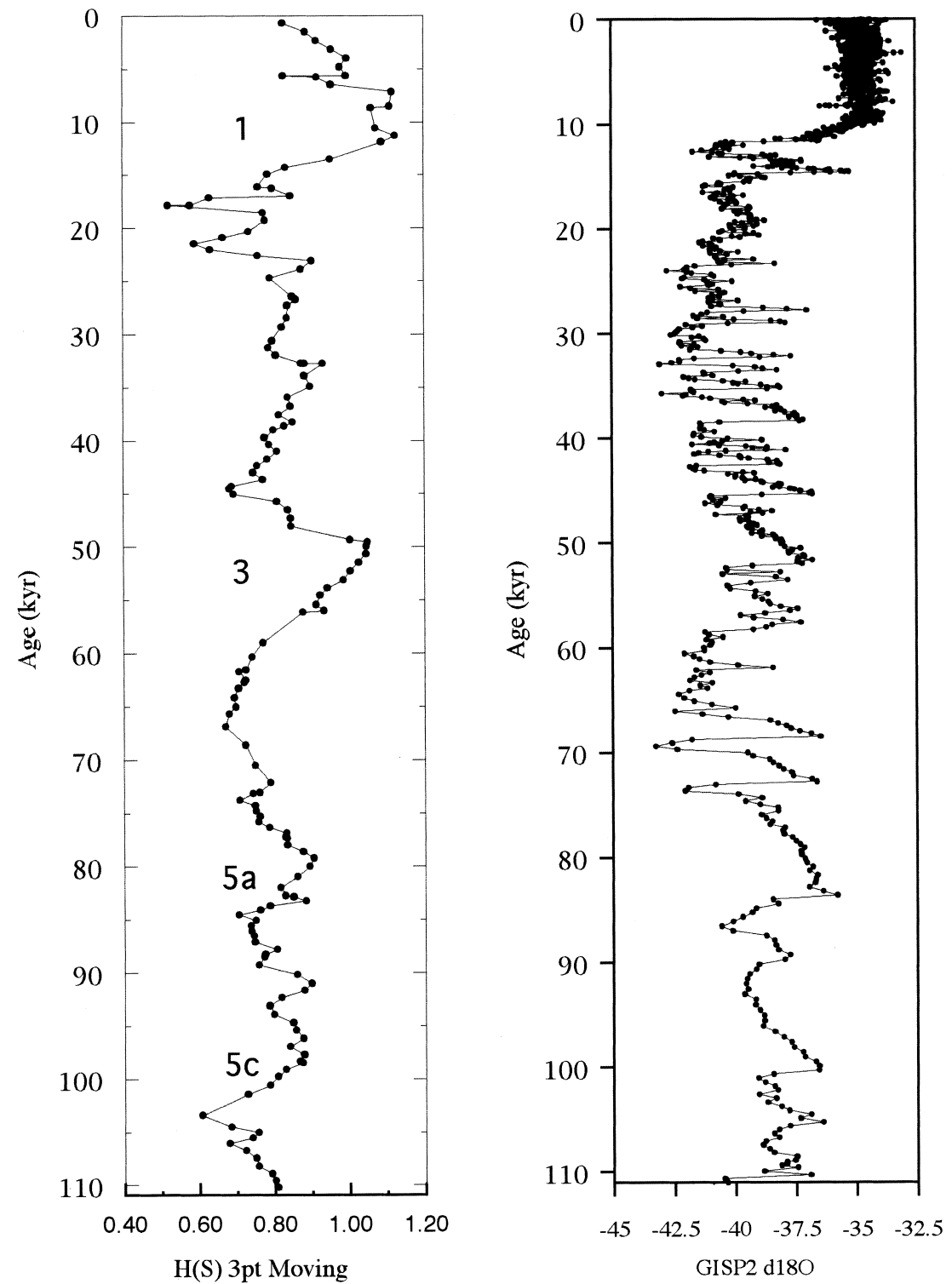

Fig. 5. Comparison of smoothed Chain core ostracode $H(S)$ with unsmoothed Greenland GISP2 ice core oxygen isotope record for past 110 kyr. High species diversity generally corresponds to light isotope values and warm climate.

moderately high diversity about 37-33 kyr corresponds to D-O events $8-5$ but the details of the two records cannot be discerned. About $16 \mathrm{kyr}$ (near 60 $\mathrm{cm}$ core depth, Fig. 2). Chain core diversity rises at a time that is tentatively correlated with $\mathrm{D}-\mathrm{O}$ event $\# 1$. Finally, the increase in diversity during the last deglaciation (Termination 1) and the early Holocene hypsithermal corresponds to the GISP2 isotopic shift to light values. While diversity decreases during the latter part of the Holocene, GISP2 isotopic record remains steady except for an important negative excursion at $8 \mathrm{kyr}$, which may correspond to the brief 
drop in diversity at 7-8 kyr in the Fig. 5 smoothed record, which is due mainly to a sharp drop from early Holocene levels near $20 \mathrm{~cm}$ core depth (Fig. 2). More detailed Holocene records are needed to confirm this relationship.

Another paleoceanographic record providing independent evidence for millennial-scale climate impacts in the deep North Atlantic Ocean is that of Rasmussen et al. (1996). Rasmussen et al. found that significant changes in surface and deepwater conditions occurred during fifteen DansgaardOeschger events of the past $150 \mathrm{ka}$ in the FaeroeShetland Channel at water depth of $1020 \mathrm{~m}$. They also documented major oscillations in the benthic foraminiferal assemblages during short-term climate events when changes in North Atlantic Deep Water occurred. Such a pattern is entirely consistent with the Chain core variability in ostracode diversity and assemblage structure discussed below.

\section{Comparison to other deep-sea ostracode records}

\subsection{Pliocene versus late Quaternary diversity}

We compared the Chain core diversity trends for late Quaternary climate oscillations with those obtained for Pliocene 41-kyr obliquity cycles from DSDP Site 607 at the Chain core site. Cronin and Raymo (1997) described a pattern of oscillating ostracode diversity during eleven 41-kyr cycles that was probably linked to variability in food resources stemming from surface ocean productivity changes described by Thomas et al. (1995) and Versteeg et al. (1996). They also documented comparable diversity instability at DSDP Site 610 in the northeastern North Atlantic Ocean on the Rockall Plateau during the Late Pliocene. At both DSDP sites, ostracode diversity oscillated from $H(S)$ values of $0.2-0.6$ during glacials and 1.2-1.6 during interglacials. This range of $H(S)$ values is quite similar to the range obtained for the late Quaternary ostracode record from the Chain core. As with the Chain core record, DSDP Site 607 was also characterized by oscillating deep-sea bottom water temperatures (Dwyer et al., 1995). Thus, it appears that late Quaternary 100kyr and Pliocene 41-kyr glacial-interglacial climatic cycles had similar impacts on deep-sea ostracode diversity in these parts of the North Atlantic Ocean, even though the amplitude of the Pliocene obliquity cycles as measured by isotopic and trace element proxies is $1 / 2$ to $1 / 3$ the amplitude of late Quaternary climatic extremes.

\subsection{Ocean margin refuges for ostracode species}

The quasi-cyclic nature of deep sea ostracode diversity means that some species inhabit deep-sea habitats intermittently, disappearing for periods of thousands to tens of thousands of years when glacial conditions exist. The question then arises as to what regions do species that are typically abundant in deep (>2500 m water depth) North Atlantic environments during interglacial periods inhabit during glacial periods? One logical place to search is shallower depths along North Atlantic continental margins. Extensive data on last glacial-Holocene interglacial ostracode faunas obtained from mid-depth (500-1500 m water depth) regions off the Little Bahama Banks provide a preliminary answer.

Slowey and Curry $(1992,1995)$ documented significant paleoceanographic changes during the last glacial at water depths just below the thermocline in the Little Bahama Banks region. Preliminary results on ostracode $H(S), S$, and $N$ from some of these sites (Fig. 6) show that upper slope habitats had greater species diversity as measured by $H(S)$ and by $S$ than do deep-sea regions like the Chain core site during both the Holocene interglacial and, on the basis of more limited data, during the last glacial (Rodriguez and Cronin, in press). Within the Little Bahama Banks region, $H(S)$ values for core 117 JPC $(1535 \mathrm{~m})$ were consistently lower $[H(S)$ about 2.0] than those for cores 7 JPC $(1320 \mathrm{~m})$ and 103 GGC $(965 \mathrm{~m})[H(S)$ about 2.5-2.8], suggesting some type of depth-related diversity gradient. Finally, the data from core 103 GGC suggest that ostracode diversity may have been lower in this region during the last glacial compared to the Holocene, although additional margins must be studied to confirm this.

The composition of the glacial-age ostracode faunal assemblages from the Little Bahama Banks suggests that there was an 'upslope migration' of certain ostracode species typically found at greater 
$\mathrm{H}(\mathrm{S})$ - Species Diversity

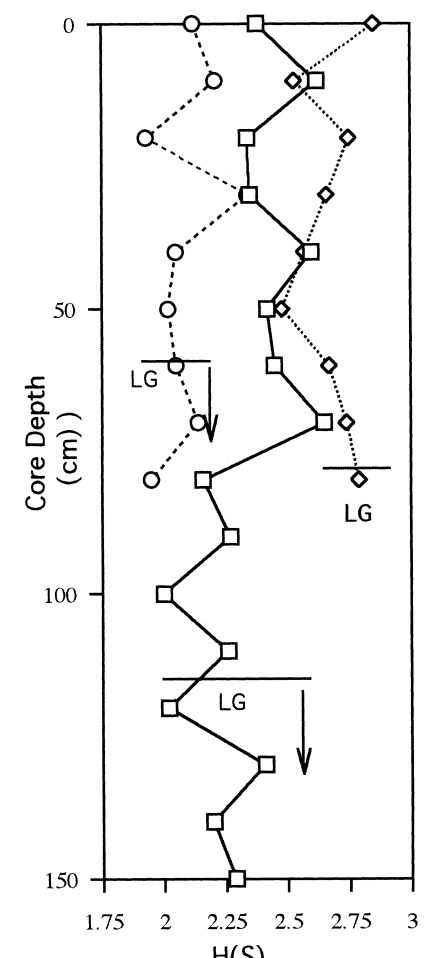

S - Number of Species

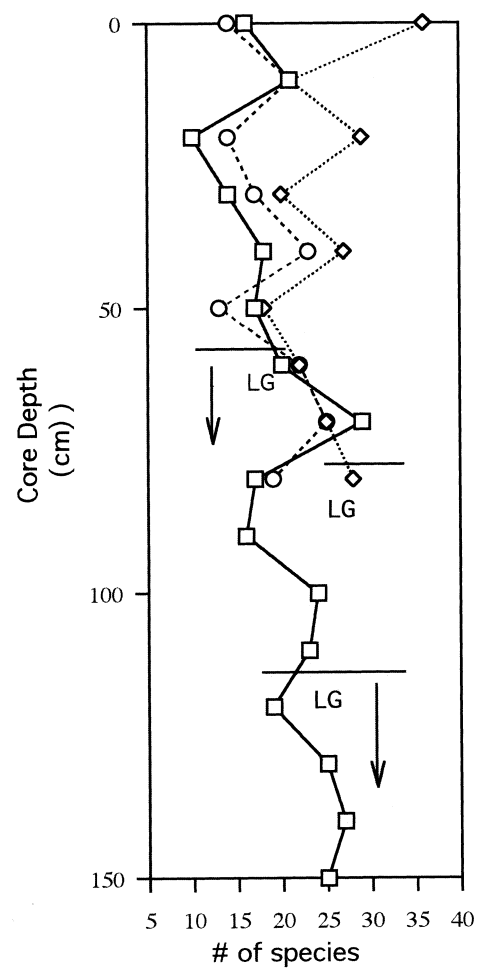

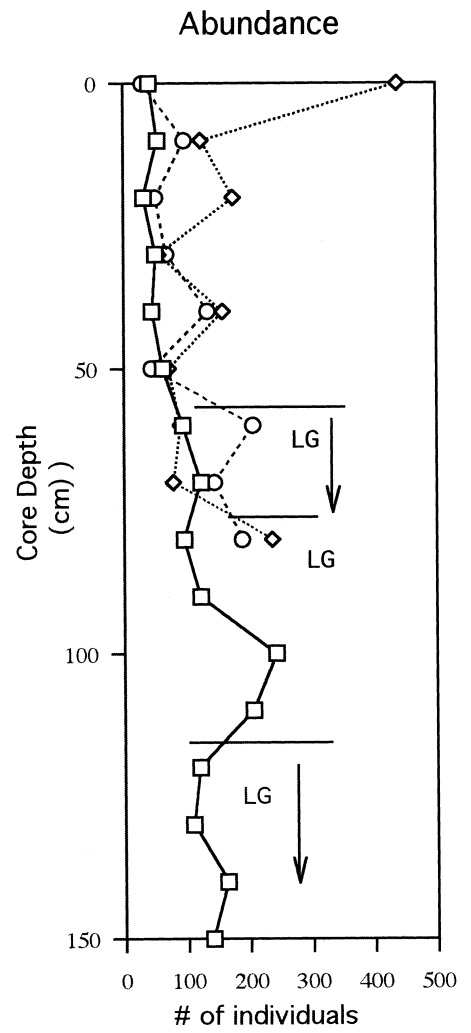

Fig. 6. Ostracode species diversity measured by $H(S)$ and $S$ and abundance for three cores from Little Bahama Bank region. Stratigraphy and paleoceanography from Slowey and Curry $(1992,1995)$. LG signifies samples believed to represent last glacial. Samples above the horizontal lines represent the deglacial and Holocene intervals.

depths. Among the more obvious examples of altered bathymetric ranges were several species of Krithe, Bradleya dictyon, and Poseidonamicus. Rodriguez and Cronin postulate that changes in bottom water conditions and food resources led to more suitable habitats in mid-depth regions during glacials, providing a temporary refuge for deep-sea species. The upslope migration hypothesis of ostracode species' paleobiogeography needs to be confirmed with additional ocean margin faunal studies in other parts of the North Atlantic. Nonetheless, it is consistent with late Quaternary changes in high-latitude ostracode species paleobathymetric distributions in response to glacial climates in several parts of the Arctic Ocean (Cronin et al., 1994, 1995) and with inferred glacial age bottom water changes based on isotopic and other proxy data. Upslope migration may be hypothesized to be a common ecological response among deep-sea species stressed by glacial oceanographic conditions.

\section{Variability in ostracode functional groups during climatic change}

Recent experimental field studies of plant diversity have shown that changes in plant species assemblage composition better explain variation in primary production and nutrient dynamics than does simple diversity of functional ecological groups (e.g., Hooper and Vitousek, 1997; Tilman et al., 1997). These studies suggest that diversity per se is not the critical factor in the functioning of an ecosystem responding to disturbance, especially in situations when the ecology of one or several key species dominate ecosystem functioning. We investi- 
gated the question of assemblage composition on the timescales of thousands to tens of thousands of years by examining variability in key functional ostracode groups in the Chain core record.

Four key ostracode assemblages were recognized in the Chain core record of the past $210 \mathrm{kyr}$ : Argilloecia/Cytheropteron, PEHO (abbreviation for a group comprised mostly of Poseidonamicus major, Echinocythereis echinata, Henryhowella asperrima, and Oxycythereis dorsoserrata), Krithe, and Pelecocythere (mainly P. foramena). Each group is dominated by a few species that possess generally similar ecological requirements and/or similar modern geographic and bathymetric distributions in the North Atlantic and adjacent seas. The species comprising each group are associated with distinct water depths, water mass characteristics, nutrient and/ or food resources. Details of many species' ecology, bathymetry, and zoogeography can be found in Whatley and Coles (1987), Dingle et al. (1990), Van Harten (1990), Coles et al. (1994), Cronin et al. (1995), and Rodriguez-Lazaro and Cronin (in press).

In addition to their modern distributions, these four groups of ostracodes also characterize distinct oceanographic stages of Pliocene 41-kyr obliquity climate cycles that can be identified based on isotopic and trace element data (Cronin et al., 1996). Krithe predominates during glacial periods, Argilloecia/Cytheropteron typically inhabit the deep North Atlantic during deglacial environments, the PEHO assemblage during peak interglacial periods, and Pelecocythere occurs almost exclusively during interglacial/glacial transitions.

We discovered secular patterns of ostracode assemblages in the Chain core late Quaternary record that were quite similar to those occurring during Pliocene climatic cycles in several important respects. Fig. 7 shows the unsmoothed trends in the proportions of these four assemblages; Fig. 8 shows a three-point moving average of the same data, excluding Pelecocythere which does not occur in enough late Quaternary assemblages to offer meaningful results. The dominant ostracode genus is Krithe; at least 10 species are found at various depths throughout the North Atlantic region (Coles et al., 1994).

We refer to the first stage of the secular pattern as the period of maximum glacial climate when the genus Krithe dominates ostracode assemblages. In deep-sea North Atlantic glacial-age sediments at water depths below about $2000 \mathrm{~m}$, Krithe is almost always the most common genus, and sometimes the sole genus present, in both Pliocene and late Quaternary sediments. Cronin et al. (1996) showed through spectral analyses that the Krithe assemblage varied at a 41-kyr frequency over 10 Pliocene climatic cycles (marine isotope stages 111-95) and its variation was coherent at the $95 \%$ confidence level and in phase with minimum $\delta^{13} \mathrm{C}$ (AABW formation), maximum $\delta^{18} \mathrm{O}$ (maximum continental ice volume), and low $\mathrm{Mg} / \mathrm{Ca}$ ratios (minimum bottom water temperature). In the Chain core record, Krithe occurs in maximum percentages ( 80 to $>90 \%$ ) during relatively cold periods corresponding to marine isotope stages $6,5 \mathrm{~d}$, 5b, 4, and 2 (Fig. 8).

The second stage is defined as a period when the Argilloecia/Cytheropteron assemblage appears immediately following the peak glacial interval. Nine Quaternary Argilloecia/Cytheropteron events are labeled $\mathrm{AC} 1$ through $\mathrm{AC} 9$ in Fig. 8 when these genera reach $>7-8 \%$ of an assemblage (maximum $>30 \%$ during late marine isotope 8 and the early Holocene stage 1). The species-level taxonomy of the former genus is not well known but most of the Chain core Argilloecia represent a single species or two or three closely related species. Cytheropteron is usually represented by between 2 to 4 species. It is well established that many species of Argilloecia and Cytheropteron typically inhabit mid-depth high-latitude Arctic and subarctic seas during the Holocene interglacial (Cronin et al., 1995; Whatley et al., 1996). The periodic occurrence of short-term increases in Argilloecia/Cytheropteron above background level of $0-3 \%$ supports the idea that during times of deglaciation, a strong pulse of North Atlantic Deep Water overflow from Nordic Seas brings a spike in the genera Argilloecia and Cytheropteron in both Pliocene and late Quaternary sequences (Cronin et al., 1996).

Following this brief peak in Argilloecia/ Cytheropteron, a third stage of a cycle corresponds to peak interglacial climates. Interglacial climates are characterized by increased proportions of the PEHO group, usually 20 to $>40 \%$ and decreased proportions of Krithe, to 40-70\%. To illustrate the temporal relationship between the Argilloecia/Cytheropteron and PEHO assemblages, dashed lines are drawn in 

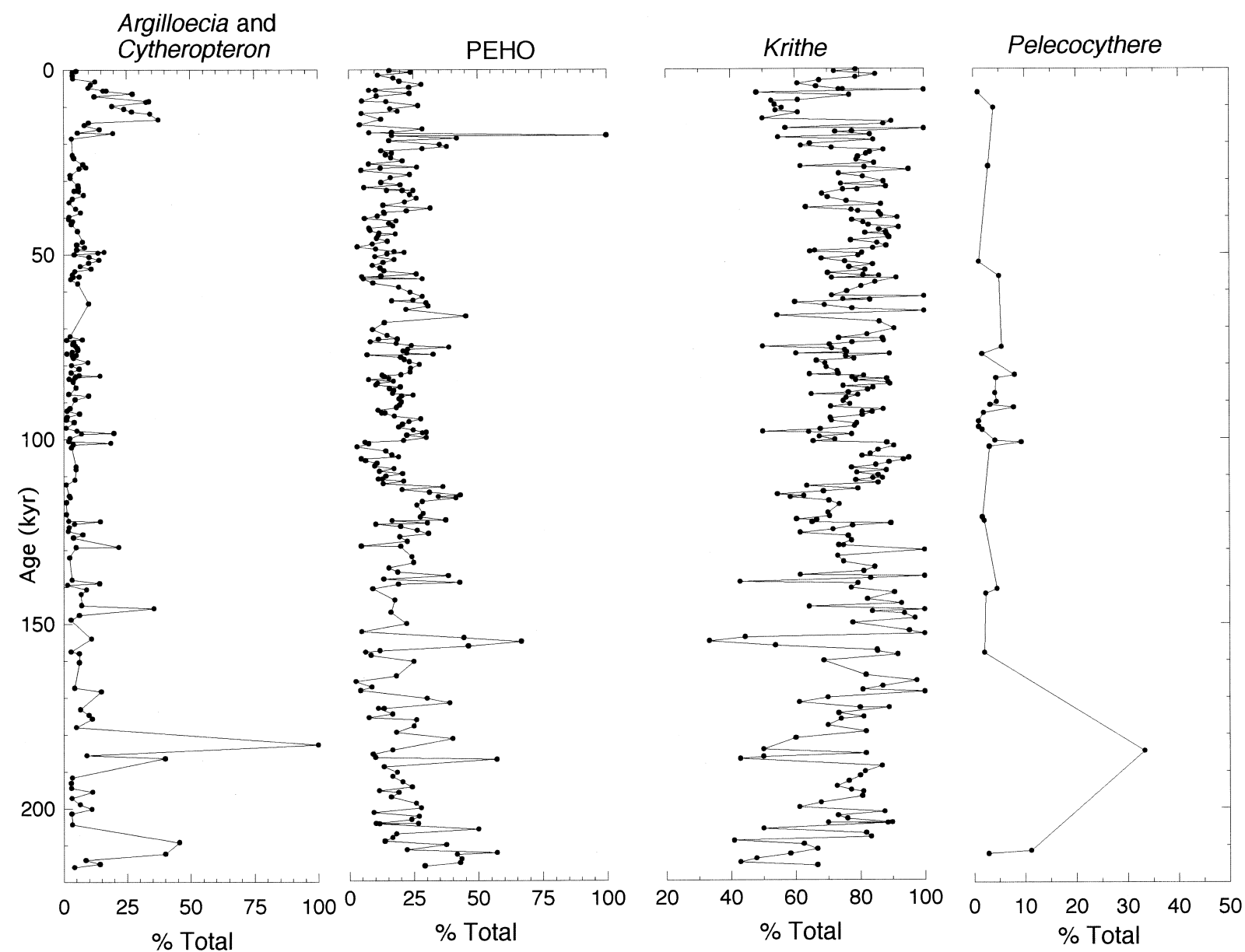

Fig. 7. Percentages of four key ostracode groups in the Chain core for the past 210 kyr. PEHO = Posiedonamicus, Echinocythereis, Henryhowella, and Oxycythereis.

Fig. 8 showing a tentative correlation between each $\mathrm{AC}$ event and a succeeding rise in PEHO. In contrast to assemblage patterns during the Pliocene 41kyr climatic cycles, the match between Argilloecia/ Cytheropteron and succeeding PEHO events in the late Quaternary is not so clearcut and additional cores will be required to sort out the succession of faunal assemblages during these suborbital climatic events.

Although occasional specimens of Pelecocythere occur in the Chain core, additional studies are needed with greater abundance to establish late Quaternary trends in Pelecocythere in the North Atlantic.

In sum, the ostracode assemblage trends shown in Figs. 7 and 8 suggest that the main features of the faunal sequences that characterized 41-kyr Pliocene climatic cycles are also typical of suborbital-scale climate oscillations of the past $210 \mathrm{kyr}$. Although it is tempting to speculate on the periodicity of ostracode assemblages and the phase relationships among them and geochemical proxy indicators, additional high sedimentation rate cores will be needed to justify spectral analyses.

\section{Discussion}

The study of biological diversity has in recent years come to the forefront as humans influence the numbers and types of species (Peters and Love- 
Percent Argilloecia/Cytheropteron

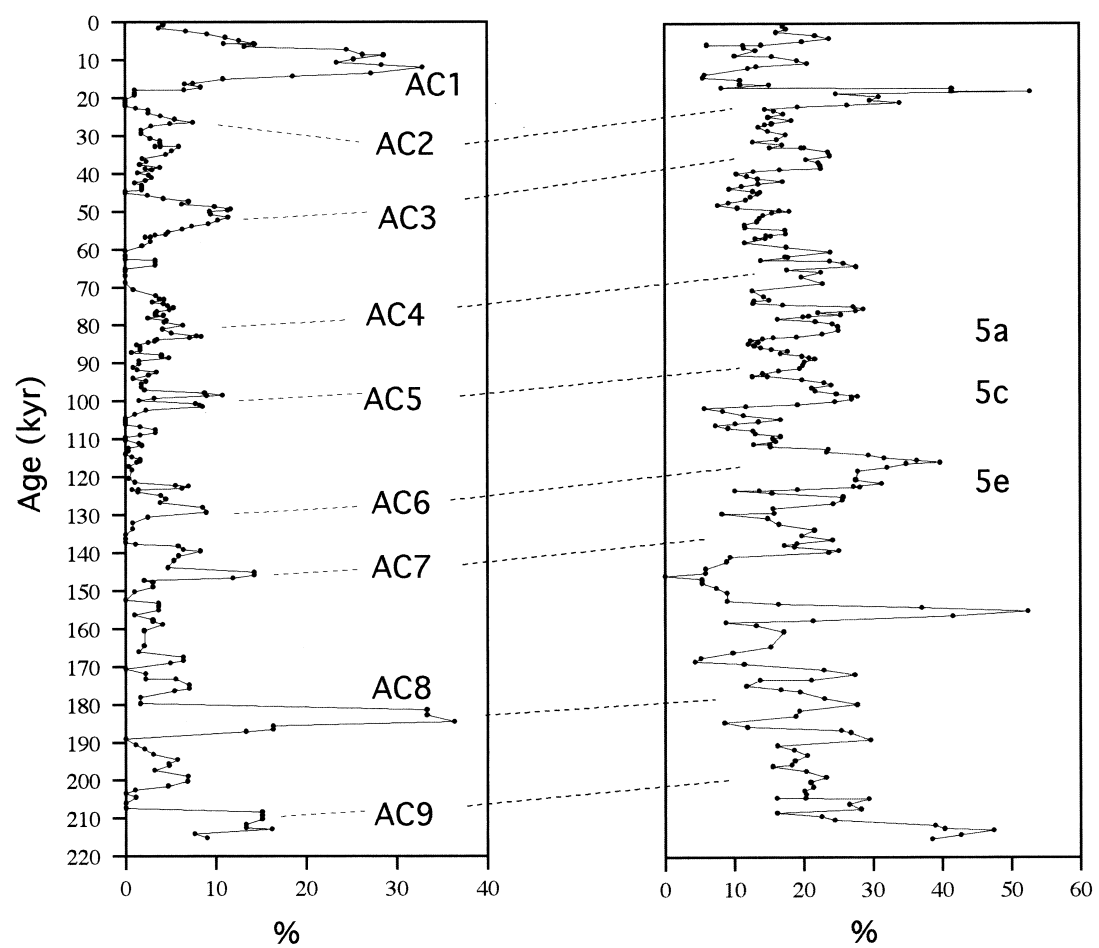

Percent Krithe

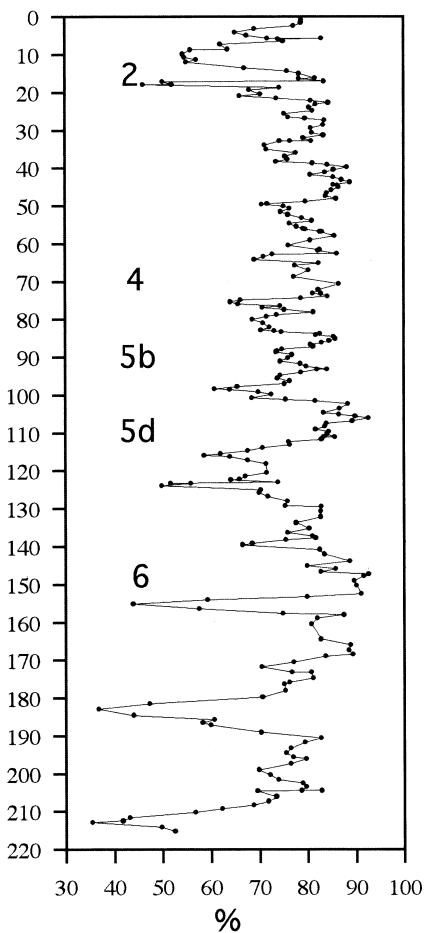

Fig. 8. Three-point moving averages of proportions of three common ostracode groups plotted in Fig. 7. ACl-AC9 are nine distinct spikes in the genera Argilloecia/Cytheropteron which signifies strong deep-water overflow probably from the Nordic Seas during deglaciation. $\mathrm{PEHO}$ is most abundant during warm periods, substages $5 a, 5 c, 5 e$; there is not a simple one-to-one correspondence of AC to $\mathrm{PEHO}$ peaks. Krithe is dominant during glacials and cool stadials, marine isotope stages $2,4,5 b, 5 d$, and 6 .

joy, 1992; Huston, 1994). Whereas many studies of species diversity have traditionally focused on small spatial and short temporal scales, some ecologists have called for a 'scaling up' of both spatial and temporal scales in studies designed to understand patterns of species diversity in general (e.g., Ricklefs, 1987; Levin, 1992; Brown, 1995) and in the deep sea in particular (Rex et al., 1993). Our results have bearing on several aspects of the relationship between environmental disturbance of deep-sea habitats due to climate changes over timescales of thousands of years and accompanying deep-sea benthic biodiversity variability.

First, as evidence mounts that deep-sea environments and deep-oceanic circulation have varied during the late Quaternary at millennial timescales (Keigwin et al., 1991; Keigwin and Jones, 1994; Oppo and Lehman, 1996), our evidence indicates that ostracode biodiversity and assemblage compo- sition also vary and that climate change plays a significant role in altering these deep-sea ecosystems. In essence, our new results extend the idea that climate exerts a primary influence on deep-sea diversity over orbital timescales (Cronin and Raymo, 1997) to suborbital timescales. The amplitude of suborbital climate events was not as great as most orbitally induced climatic cycles, but our results nevertheless indicate significant short-term modification of deep-sea benthic ecosystems.

One obvious implication of these data in terms of future climate change is the potential sensitivity of deep-sea ecosystems to relatively small changes in deep-ocean circulation changes. If the ostracode assemblage is assumed to be a relatively accurate proxy for the entire benthic community of a region, then it appears that the deep sea ecosystem is not immune to climate perturbations experienced in surface waters and terrestrial environments. Although the 
fine spatial fabric of biodiversity cannot be inferred from one or two cores from a site, the hypothesis that observed diversity variability characterizes a large region of the deep North Atlantic and perhaps other ocean basins can be tested.

More generally, our results support the ideas of Rex et al. (1993) that different mechanisms control diversity trends at different spatial and temporal scales. While it may be true, as argued by Etter and Grassle (1992), that at small spatial scales, sediment composition correlates most strongly with diversity in deep-sea soft sediment communities, climate changes may ultimately be a major influence on surface water productivity and seasonal and interannual phytodetrital fluxes to the bottom (Gooday, 1988; Thomas et al., 1995; Versteeg et al., 1996).

Finally, large-scale spatial and temporal patterns of deep-sea biodiversity are still poorly understood. Although we have not yet studied ostracodes from sedimentary sequences in the North Atlantic having a sub-millennial scale resolution, we suspect on the basis of our observations of Quaternary assemblages from the Nordic Seas that ostracode assemblage response to even shorter-scale perturbations will be pronounced. Consequently, one ultimate goal might be to obtain decadal and centennial scale diversity records which would provide at least a preliminary means of understanding natural levels of diversity variability prior to and since humans have begun to modify climate. Moreover, as improved paleoclimate and biodiversity records at centennial timescales become available from deep-sea sites (Keigwin, 1995), it is not inconceivable that temporal resolution approaching that of experimental diversity data sets (Tilman et al., 1997) might be achieved. Such a marriage between experimental field studies and retrospective analyses of diversity would be unprecedented and provide valuable data on how ecosystems respond to perturbation and how human activities might be altering diversity in the oceans.

\section{Acknowledgements}

We are grateful to Lloyd D. Keigwin and Edward A. Boyle for kindly loaning us Chain core samples and providing isotopic and trace elemental data. This study was supported by the USGS Global
Change and Climate History Program and National Science Foundation Grant OCE-9726090 to GSD. We appreciate the comments of D.A. Willard and H.D. Dowsett and two anonymous referees on the manuscript and the support of Alan Lord and Ian Boomer in the development of this paper.

\section{References}

Alley, R.B., Mayewski, P.A., Sowers, T., Stuiver, K., Taylor, C., Clark, P.U., 1997. Holocene climatic instability: A prominent, widespread event 8200 yr ago. Geology 25, 483-486.

Boyle, E.A., Keigwin, L.D., 1982. Deep circulation of the North Atlantic over the last 200,000 years: Geochemical evidence. Science 218, 784-787.

Boyle, E.A., Keigwin, L.D., 1985. Comparison of Atlantic and Pacific paleochemical records for the last 215,000 years: Changes in deep ocean circulation and chemical inventories. Earth Planet. Sci. Lett. 76, 135-150.

Boyle, E.A., Keigwin, L.D., 1987. North Atlantic thermohaline circulation during the past 200,000 years linked to high-latitude surface temperature. Nature 330, 35-40.

Broecker, W.S., Peteet, D.M., Rind, D., 1985. Does the oceanatmosphere system have more than one stable mode of operation. Nature 315, 21-26.

Brook, E.J., Sowers, T., Orchado, J., 1996. Rapid variations in atmospheric methane concentration during the past 110,000 years. Science 273, 1087-1090.

Brown, J.H., 1995. Macroecology. Univ. Chicago Press, Chicago, IL.

Coles, G., Whatley, R., Moguilevsky, A., 1994. The ostracode genus Krithe from the Tertiary and Quaternary of the North Atlantic. Palaeontology 37, 71-120.

Cronin, T.M., 1996. Deep water North Atlantic ostracods and Pliocene paleoceanography (3.2-2.8 Ma) DSDP sites 610A and 607. In: Moguilevsky, A., Whatley, R. (Eds.), Microfossils and Oceanic Environments. Univ. Wales, Aberystwyth Press, pp. 39-46.

Cronin, T.M., Raymo, M.E., 1997. Orbital forcing of deep-sea benthic species diversity. Nature 385, 624-626.

Cronin, T.M., Holtz Jr., T.R., Whatley, R.C., 1994. Quaternary paleoceanography of the deep Arctic Ocean based on quantitative analysis of Ostracoda. Mar. Geol. 119, 305-332.

Cronin, T.M., Holtz, T.R., Stein, R., Spielhagen, R., Futterer, D., Wollenburg, J., 1995. Late Quaternary paleoceanography of the Eurasian Basin, Arctic Ocean. Paleoceanography 10, 259-281.

Cronin, T.M., Raymo, M.E., Kyle, K.P., 1996. Pliocene (3.2-2.4 Ma) ostracode faunal cycles and deep ocean circulation, North Atlantic Ocean. Geology 24, 695-698.

Cronin, T.M., Dwyer, G.S., Baker, P.A., Rodriquez-Lazaro, J., 1999. Orbital and suborbital variability in North Atlantic Bottom Water temperatures obtained from deep-sea ostracode $\mathrm{Mg} / \mathrm{Ca}$ ratios. Palaeogeogr., Palaeoclimatol., Palaeoecol. (submitted). 
Dansgaard, W., Johnsen, S.J., Clausen, H.B., Dahl-Jensen, D., Gundestrup, N.S., Hammer, C.U., Hvldberg, C.S., Steffensen, J.P., Sveinbjornsdottir, A.E., Jouzel, J., Bond, G., 1993. Evidence for general instability of past climate from a 250-kyr ice-core record. Nature 364, 218-220.

Dingle, R.V., Lord, A.R., Boomer, I.A., 1990. Deep water Quaternary Ostracoda from the continental margin of south-western Africa (SE Atlantic Ocean). S. Afr. Mus. Ann. 99, 245366.

Dwyer, G.S., Cronin, T.M., Baker, P.A., Raymo, M.E., Buzas, J.S., Correge, T., 1995. North Atlantic deep-water temperature change during late Pliocene and late Quaternary climatic cycles. Science 270, 1347-1351.

Etter, R.J., Grassle, J.F., 1992. Patterns of species diversity in the deep sea as a function of sediment particle size. Nature 360 , 576-578.

Gooday, A., 1988. A response by benthic foraminifera to the deposition of phytodetritus in the deep sea. Nature 332, 7073.

Hessler, R.R., Sanders, H.L., 1967. Faunal diversity in the deep sea. Deep-Sea Res. 14, 65-78.

Hooper, D.U., Vitousek, P.M., 1997. The effects of plant composition and diversity on ecosystem processes. Science 277, 1302-1305.

Huston, M.A., 1994. Biological Diversity. Cambridge Univ. Press, Cambridge.

Johnsen, S.J., Clausen, H., Dansgaard, W., Fuhrer, K., Gundestrup, N.S., Hammer, C.U., Iverssen, P., Jouzel, J., Stauffer, B., Steffensen, J.P., 1992. Irregular glacial interstadials recorded in a new Greenland ice core. Nature 359, 311-312.

Keigwin, L.D., Jones, G.A., 1994. Western North Atlantic evidence for millennial-scale changes in ocean circulation and climate. J. Geophys. Res. 99, 12397-12410.

Keigwin, L.D., Jones, G.A., Lehman, S.J., Boyle, E.A., 1991. Deglacial meltwater discharge, North Atlantic deep circulation and abrupt climatic change. J. Geophys. Res. 96, 1681116826.

Keigwin, L.D., 1995. The Little Ice Age and Medieval Warm Period in the Sargasso Sea. Science 274, 1504-1508.

Lehman, S.J., Keigwin, L.D., 1992. Sudden changes in North Atlantic circulation during the last deglaciation. Nature 356, 757-762.

Levin, S.A., 1992. The problem of pattern and scale in ecology. Ecology 73, 1943-1967.

Manabe, S., Stauffer, R., 1995. Simulation of abrupt climate change induced by freshwater input to the North Atlantic Ocean. Nature 378, 165-167.

Oppo, D.W., Lehman, S.J., 1996. Suborbital timescale variability of North Atlantic deep water during the past 200,000 years. Paleoceanography 10, 901-910.

Peters, R.H., Lovejoy, T.E. (Eds.), 1992. Global Warming and the Biological Diversity Crisis. Yale Univ. Press, New Haven, CT.

Rasmussen, T.L., Thomsen, E., Van Weering, T.C.E., Labeyrie, L., 1996. Rapid changes in surface and deep water conditions at the Faeroe Margin during the past 58,000 years. Paleoceanography $11,757-771$.
Raymo, M.E., Ruddiman, W.F., Backman, J., Clement, B.M., Martinson, D.G., 1989. Late Pliocene variation in the Northern Hemisphere ice sheets and North Atlantic deepwater circulation. Paleoceanography 4, 413-446.

Raymo, M.E., Hodell, D., Jansen, E., 1992. Response of deep ocean circulation to initiation of Northern Hemisphere glaciation (3-2 Ma). Paleoceanography 7, 645-672.

Rex, M.A., Stuart, C.T., Hessler, R.R., Allen, J.A., Sanders, H.L., Wilson, G.D.F., 1993. Global-scale latitudinal patterns of species diversity in the deep-sea benthos. Nature 365, 636639.

Ricklefs, R.E., 1987. Community diversity: Relative roles of local and regional processes. Science 235, 167-171.

Rodriguez-Lazaro, J., Cronin, T.M., in press. Quaternary glacial and deglacial Ostracoda from the Little Bahama Banks: Paleoceanographic implications. Palaeogeogr., Palaeoclimatol., Palaeoecol. (in press).

Ruddiman, W.F., Raymo, M.E., Martinson, D.G., Clement, B.G., Backman, J., 1986. Pleistocene evolution: Northern Hemisphere ice sheets and North Atlantic Ocean. Paleoceanography 4, 353-412.

Schnitker, D., 1979. The deep waters of the western North Atlantic during the past 24,000 years, and the re-initiation of the western boundary undercurrent. Mar. Micropaleontol. 4, 265-280.

Slowey, N.C., Curry, W.B., 1992. Enhanced ventilation of the North Atlantic subtropical gyre thermocline during the last glaciation. Nature 358, 665-668.

Slowey, N.C., Curry, W.B., 1995. Glacial-interglacial differences in circulation and carbon cycling within the upper western North Atlantic. Paleoceanography 10, 715-732.

Stuiver, M., Grootes, P.M., Brazunias, T.F., 1995. The GISP $\delta^{18} \mathrm{O}$ record of the past 16,500 years and the role of the Sun, ocean, and volcanoes. Quat. Res. 44, 341-354.

Thomas, E., Booth, L., Maslin, M., Shackleton, N.J., 1995. Northeastern Atlantic benthic foraminifera during the last 45,000 years: Changes in productivity seen from the bottom up. Paleoceanography 10, 545-562.

Tilman, D., Knops, J., Wedin, D., Reich, P., Ritchie, M., Siemann, E., 1997. The influence of functional diversity and composition on ecosystem processes. Science 277, 1300-1302.

Van Harten, D., 1990. Modern abyssal ostracod faunas of the eastern mid-Atlantic Ridge area in the North Atlantic and a comparison with the Mediterranean. In: Whatley, R., Maybury, C. (Eds.), Ostracoda and Global Events. Chapman-Hall, London, pp. 321-327.

Versteeg, G.J.M., Brinkhuis, H., Visscher, H., Zonneveld, K.A.F., 1996. The relation between productivity and temperature in the Pliocene North Atlantic at the onset of northern hemisphere glaciation: a palynological study. Global Planet. Change 11, 155-165.

Whatley, R., Coles, G.P., 1987. The late Miocene to Quaternary Ostracoda of Leg 94, Deep Sea Drilling Project. Rev. Esp. Micropaleontol. 19, 33-97.

Whatley, R., Eynon, M., Moguilevsky, A., 1996. Recent Ostracoda of the Scoresby Sund Fjiord system, East Greenland. Rev. Esp. Micropaleontol. 28, 5-23. 